\title{
Financial Sustainability of Small Farmer Cooperative (SFC) in Mid- Western Region of Nepal
}

\section{Liladhar Tiwari ${ }^{1}$ and Govind Nepal ${ }^{2}$}

${ }^{1} \mathrm{PhD}$ Scholar, Mewar University, Chittorgarh, Rajasthan, India

${ }^{2}$ Research Supervisor, Professor, Tribhuvan University.

\section{Corresponding Author}

Liladhar Tiwari

Email: liladhar70@gmail.com

\section{ABSTRACT}

This article is based on Financial Sustainability of Small Farmers Cooperative (SFC) in MidWestern of Nepal. It attempts to provide the practices and their impacts of financial sustainability of SFC. As the cooperative movement originated from the philosophy of cooperation and later developed as a powerful tool to support to improve socio-economic position of resource poor, vulnerable, members of the lower caste people, women, labors and peasants, the SFC functions with the guiding philosophy of group principle, self-help development and institutionalization of networks at the grassroots level to reduce the scarcity. This study applied a descriptive and analytical research design using both primary (observation; questionnaires, focused group discussion) and secondary (Department of Cooperative (DoC), Central Bureau of Statistics (CBS), and National Cooperative Federation of Nepal (NCF/N and annual report of sampled cooperatives) sources of data. After the analysis and interpretation of data, a number of contributions were found such as saving collection, credit investment, socio-economic development etc. The SFCs were found to be guided by self-governing norms and shares were issued to the members who are empowered with one member one vote for the general assembly purpose. The institutions function for socio-economic development with the strong policy of being apolitical and unbiased with no discrimination of any kind on religion and gender basis. The socioeconomic position of cooperative members has changed through income generating programs. This study is concentrated on perception study of the financial sustainability of Small Farmer Cooperative (SFC) for the economic as well as financial development.

\section{KEYWORDS}

Financial, Sustainability, Small Farmer Cooperative (SFC), Correlation, Development.

\section{INTRODUCTION}

The word 'cooperative' is derived from the Latin word 'cooperari', that means working together with others. In the simple words, cooperation is a 'give and take' process to each other, working together for similar and a common cause. For the long time in the history, cooperation remains in informal setting with different kinds of beings. Until around 200 years ago, people were living in the village communities, tribes and large extended families and even in the city where people felt 
at home and shared the problems and happiness. The cooperative movement originated from the philosophy of cooperation and later developed as a powerful tool to support improving socioeconomic status of resource poor, vulnerable, members of the lower caste people, women, labors and peasants. Furthermore, cooperative promotes cohesiveness, mutual supports and congenial environment in the society. Cooperative principles have proved that small efforts of many people would make large contribution in socio-economic development of a society (Neupane, 2006).

The main aim of cooperative organizations is to improve socio-economic position of rural people by creating cooperation and mutual support each other. Basic features of cooperatives are to organize community people into the groups, collect savings for the loan investment and social activities, share ideas on community social and economic development, empower grassroots people, grasp financial resources, access technical assistance from the related other development agencies, develop self-operating financial institutions at the local/village level. Therefore, the cooperation means association of a number of people in enterprises for mutual benefits. The motto of cooperation is 'each for all and all for each'. Cooperation was developed as a universal instrument of creation to release workers from exploitation and retain benefits for themselves (Neupane, 2006).

Cooperative confidently follows seven principles like voluntary and open membership, democratic process, financial contribution from members, freedom of autonomy and independence, education \& Regular training, cooperation among cooperatives and concern for community to promote and strengthen their institution to achieve the major goal of socio-economic development all over the world (Devkota, 2009).

Cooperative was initiated since the beginning of the $18^{\text {th }}$ century by Robert Owen (17711858) in England and Charles Fourier (1772-1837), Philippe J.B Bunchez (1796-1865) and Louis Blanc (1811-1882) in France had influenced development of the concept of modern cooperatives (Rhodes, 1995). The International Cooperatives Alliance (ICA) was established in 1985. It made two formal declarations in cooperative principles in 1937 and 1966. Agricultural cooperative was initiated in the period from 1945 to 1960 and its network expended widely during 1960 to 1970 (Badal, 2004).

Cooperatives as the communitarian informal institutions have been traditionally embedded in the social and cultural traditions of Nepal. The Constitution of Nepal (2015) has considered cooperative sector as an important pillar for national economic development together with public and private sectors. Guthis (religious trusts), Dharma Bhakaris (religious-oriented food grain stores), Parma (mutual labour exchange) are a few instances. The formal genesis of the cooperative can be traced backed to April 2, 1956 with the foundation of Bakhanpur credit cooperative in Chitwan district. Later in 1959, cooperative societies Act (2016) were enacted. Despite the several revisions of the first Cooperative Societies Act, it was finally replaced by the Sajha Societies Act in 1984. With the restoration of multiparty democracy in 1990, the Sajha Societies Act was replaced again by the Cooperatives Act in 1992 which has accepted the fundamental cooperative principles and created a legal base both for setting up the cooperative societies and translation of cooperative values, norms and principles into practice $(\mathrm{NCF} / \mathrm{N}, 2014)$. 
Currently, according to the Department of Cooperative (DoC), there are 32,663 primary cooperatives in existence. Cooperative sector contributes in GDP, approximately 3 percent and in financial sector 21 percent. Therefore, cooperative sector is most important sector for economic development of Nepal (DoC, 2015).

Agricultural Development Bank of Nepal had launched Small Farmers Development Program for two decades with the support of the Government of Nepal and Asian Development Bank for the upliftment of the small farmers. Small farmers were defined in terms of annual income less than NRs. 9000 and land holding less than one Pakki Bigha(two acres) in Tarai and around twelve Ropani (nearly 600 sq. meters/ ropani) in mountain and hilly areas. Farmers groups were organized and the loan was disbursed in recommendation of the group and the chairpersons were responsible persons for the preparation of group bonds. Small Farmers Cooperative was organized with the whole group members of the SFDP as members and the loan provided by the ADB/N was transferred to Small Farmers Cooperative Limited (Thakuri, 2010).

ADBL (1993) has helped publish the By-laws of the Small Farmers Cooperative Limited (SFCL) to provide basic rules and regulations of the cooperatives. General assembly is one of the most powerful authorities of SFCLs. It has full authority to prepare policies, procedure of SFCLs on the one hand and an approval of last year's expenditure and current year's program and budget on the other. Apart from this, it nominates auditors and finalizes staff salary for the current year. There must be at least 25 general members to be registered as a cooperative institution. General assembly is organized once a year at the end of fiscal year. General assembly elects the members of main committee including Chairperson, Vice-chairperson, Secretary, Treasurer and Members from among the general members. Management of SFCLs is guided and controlled by the main committee, so that certain accountabilities such as office management, accounting and loan management are handed-over to the staff of SFCLs. The main committee is fully accountable to loan investment, collection and enrollment of new members. Major functions of the main committee are loan investment, collection, and domestic resource mobilization, meeting organization, coordination, supervision, and follow-up and monitoring. In addition, executive committee could implement awareness development activities, empowerment development and community mobilization activities for development of their particular areas (Devkota, 2009).

The program would meet the needs of the members through resources raised on their own strength, either from among themselves or from external sources. Though sustainability does get understood immediately in the financial terms or the resource terms, it actually has broader dimensions, of which financial sustainability is a one major dimension of financial position of the organization.

Small Farmers Cooperative (SFC) is a multi-service cooperative designed to deliver primarily financial, but also non-financial services to its members in rural areas. SFCs are civil society organizations, which pool their joint resources to meet basic needs and to defend their members' interests. They are member-owned and controlled and have an open membership policy towards "poor" farmers. SFCs deliver various financial and non-financial services. Financial services include various forms of voluntary and compulsory savings products, a variety of loan 
products as well as a livestock insurance scheme. Non-financial services include construction of irrigation channels, establishment of milk collection centers, nursery programs and women empowerment programs as well.

\section{METHODOLOGY}

This study applied a descriptive and analytical research design in the specific area. For the study purpose, both quantitative and qualitative tools were used to collect data. Relevant literature was received as required by this research topic and later on tried to generalize it. Purposive sampling technique was used to select the SFC established by the different castes, areas, constituencies of Mid-western Region of Nepal. Besides that, member of cooperatives were selected by using the lottery system of simple random sampling without replacement. This was done to obtain an unbiased and fair study. Sampling SFCs were taken from sampled three districts (Banke, Surkhet and Jumla). Data was collected from the 570 members of sampled seven (Mahadevpuri, Naubasta, Chisapani, Mehelkuna, Latikoilee, Uttarganga and Karnali) SFCs. The present study primarily relies upon primary as well as secondary data. Data collections have been carried out through the structured questionnaire and focused group discussion. Use of the correlation (r) provides determination of dependent and independent variables for analysis of data.

\section{RESULTS AND DISCUSSION}

According to the Statistics of Cooperative Enterprises (Department of Cooperative) 2015, in the Mid-western Development Region, total 1492 Agriculture cooperatives are registered of which 188 are in Banke, 279 in Surkhet, and 48 in Jumla and other excess agriculture cooperatives are in existence in different districts of Mid-Western Region of Nepal. Small Farmers Cooperatives (SFCs) are functioning together with Agriculture Cooperatives. Among total 34 SFCs, 10 SFCs in Banke district, 22 SFCs in Surkhet district and only 2 SFCs are functioning in Jumla district. Out of them, only seven sampled SFCs are taken for this study.

There are a total of 7079 share members, among them 5551 are female and 1528 are male from seven sampled cooperatives in three (Banke, Surkhet and Jumla) districts. Only 570 households of 7079 share members are taken as sample unit while gathering the data collection for information. Each sampling unit from member of cooperatives is selected by lottery system and by simple random sampling without replacement. This was done to obtain a fair as well as unbiased study.

The objective of this study is to present how cooperatives are financially sustained and calculate the relationship between different variables of financial sustainability of cooperatives. The variables- total members, savings, investments (loan disbursement), net profits, assets, loan investments, loan refunds, loan balances are taken into consideration. Correlation (r) and other analysis part t-value and p-value are calculated for the interpretation of result. 


\section{Relationship between Demographic Variables and Financial Sustainability of Sampled SFC}

Table 1 presents the relationship between demographic variables and financial sustainability variables such as total members, investments, savings, net profits, assets, loan refunds and loan balances of SFCs.

According to the presented data in Table 1 the relation between total member and investment (loan disbursement) in Tarai, correlation coefficient (r) is $(0.891)$, p-value is $(0.000)$ and in Hills, correlation coefficient (r) is (0.782), p-value is $(0.001)$, which are lower than 0.05 . Therefore, at $5 \%$ of level of significance, the null hypothesis is rejected. Hence, there is strong positive correlation between these two variables. It is found that there is significant relationship between total member and investment of cooperative.

The reason is that collected amount should be invested through the cooperative member. Large scale of amount should easily be invested or delivered through the large scale of members of cooperative. Therefore, it is a positive relationship between investment and total member of cooperative society.

Table 1: Correlations between the Different Variables

\begin{tabular}{|l|l|l|l|l|}
\hline Relationship & $\begin{array}{l}\text { Ecological } \\
\text { Zone }\end{array}$ & Correlation(r) & P-value & Remarks \\
\hline Total Member with Investment & Tarai & .891 & .000 & \\
& Hill & .782 & .001 & Significant \\
\hline Total Member with Saving & Tarai & .825 & .000 & \\
& Hill & .758 & .001 & Significant \\
\hline Total Member with Net Profit & Tarai & .859 & .000 & \\
& Hill & .782 & .000 & Significant \\
\hline Saving with Investment (Loan & Tarai & .935 & .000 & \\
disbursement & Hill & .990 & .000 & Significant \\
\hline Saving with Net Profit & Tarai & .957 & .000 & \\
& Hill & .656 & .008 & Significant \\
\hline Assets with Net Profit & Tarai & .386 & .155 & \\
& Hill & .523 & .045 & Insignificant \\
\hline Loan investment with Loan Refund & Tarai & .893 & .000 & \\
& Hill & .967 & .000 & Significant \\
\hline Loan investment with Loan Balance & Tarai & 1.000 & .000 & \\
& Hill & .940 & .000 & Significant \\
\hline
\end{tabular}

Sources: Field Survey, 2015

Similarly, the relation between saving and membership of cooperative in Tarai, correlation coefficient (r) is $(0.825)$, p-value is $(0.000)$ and in Hills, correlation coefficient ( $r)$ is $(0.758)$, pvalue is $(0.001)$ which are lower than 0.05 . Therefore, at $5 \%$ of level of significance, the null 
hypothesis is rejected. Hence, there is a strong positive correlation between these two variables. It is found that there is a compact relationship between saving and total member of cooperative in Tarai and Hill area of Mid-western region. It is statistically significant.

The main reason behind the strong correlation between these two variables (saving and total member) is that increment in total members increases the total saving amount of cooperative. Increasing in saving helps to generate the funds of cooperative. Hence, there is a strong relation between saving and total members of cooperative.

Table 1 presents the relation between size of member and net profit of cooperative in Tarai, correlation coefficient (r) is (0.859), p-value is $(0.000)$ and in Hills, correlation coefficient $(r)$ is (0.782), p-value is $(0.000)$ which are lower than 0.05 . Therefore, at $5 \%$ of level of significance, the null hypothesis is rejected. There is a strong positive correlation between these two variables. It is found that there is a close relationship between membership and net profit of cooperative in Tarai and Hills of the study area is statistically significant.

The main reason behind the strong correlation between these variables is that increment in total membership increased the total saving and credit amount of cooperative as well. Saving and credit amount has direct effects on volume of transaction and net profit of cooperative organization. Hence, there is a strong relationship between membership and net profit of cooperative.

Likewise, the relation between saving and investment (loan disbursement) of cooperative in Tarai, correlation coefficient ( $r)$ is $(0.935)$, p-value is $(0.000)$ and in Hills, correlation coefficient (r) is $(0.990), \mathrm{p}$-value is $(0.000)$ which are lower than 0.05 . Therefore, at $5 \%$ of level of significance, the null hypothesis is rejected. Hence, there is a strong positive correlation between these two variables. It is found that there is a close relationship between saving and investment (loan disbursement) of cooperative in Tarai and Hills of the study area is statistically significant.

The main reason behind the strong correlation between these two (saving and investment) variables is that increment in total saving amount increased the environment of loan investment of cooperative. Saving amount has direct effects on loan disbursement of cooperative. Hence, there is a strong relationship between saving and investment of cooperative society.

The relation between saving and net profit of cooperative in Tarai, correlation coefficient (r) is (0.957), p-value is ( 0.000$)$ and in Hills, correlation coefficient $(r)$ is $(0.656)$, p-value is $(0.008)$ which are lower than 0.05 . Therefore, at $5 \%$ of level of significance, the null hypothesis is rejected. Hence, there is a strong positive correlation between these two variables. It is found that there is a high relationship between saving and net profit of cooperative in Tarai and medium relationship between saving and net profit in Hills of the study area which is statistically significant.

The main reason behind the strong correlation between these two (saving and net profit) variables is that increment in total saving amount increased the environment of loan investment and loan refund of cooperative. Increased in saving and credit (loan) activities should be possible to gain the high profit of the cooperative. Otherwise, it is impossible to gain net profit without increase in saving and give a loan activity. Hence, there is a strong relationship between saving and net profit of cooperative society. 
In the same way, the relation between assets and net profit of cooperative in Tarai, correlation coefficient ( $\mathrm{r}$ ) is (0.386), p-value is $(0.155)$ and in Hills, correlation coefficient (r) is (0.523), p-value is $(0.045)$ which are higher than 0.05 . Therefore, at $5 \%$ of level of insignificance, the null hypothesis is accepted. It is found that there is no correlation between assets and net profit of cooperative in Tarai and positive correlation between assets and net profit in Hills of the study area which is statistically insignificant.

The reason behind the no correlation between these two (assets and net profit) variables is that increment in assets do not increase the net profit of cooperative. Assets should be essential condition for strengthen an organization but not sufficient condition to increase the net profit of a cooperative. Hence, there is no relationship between assets and net profit of cooperative society in Tarai.

Table 1 also indicates the relation between loan investment and loan refund of cooperative in Tarai, correlation coefficient (r) is (0.893), p-value is (0.000) and in Hills, correlation coefficient (r) is (0.967), p-value is (0.000) which are lower than 0.05 . Therefore, at $5 \%$ of level of significance, the null hypothesis is rejected. Hence, there is strong positive correlation between these two variables. It is found that there is a positive relationship between loan investment and loan refund of cooperative in Tarai and in Hills area of Mid-western region which is statistically significant.

The main reason behind the strong relationship between these two (loan investment and loan refund) variables is that the interrelated component for the progress of cooperative. Without loan investment and scheduler loan refund activities, cooperative does not achieve the goal of organization. Hence, there is intensely a positive relationship between loan investment and loan refund in time for the development of the cooperative society.

Likewise, the relation between loan investment and loan balance of cooperative in Tarai, correlation coefficient (r) is (1.000), p-value is (0.000) and in Hills, correlation coefficient (r) is (0.940), p-value is (0.000) which are lower than 0.05 . Therefore, at $5 \%$ of level of significance, the null hypothesis is rejected. It is found that there is a perfect positive correlation between loan investment and loan balance of cooperative in Tarai and strong correlation between loan investment and loan balance in Hills area of Mid-western region which is statistically significant.

The main reason behind the strong correlation between these two (loan investment and loan balance) variables is the strong interrelated part for the progress of cooperative organization. Without loan investment and in time loan refund activities, cooperative does not complete the aim of organization. Loan collection is more important than the loan investment activities for the sustainability of cooperative. Excess of huge amount of loan balance creates in decreasing position of cooperative. Hence, there is a perfectly positive relationship between loan investment and loan balance for the progress of the cooperative society.

\section{CONCLUSIONS}

Vol. 4. No. II

www.phdcentre.edu.np 
The correlation coefficient (r) and p-value examine the relationship among different variables of financial sustainability of SFCs. The relationship between size of members and investment is statistically significant. Thus, there is a positive relationship between investment and total member of cooperative society. Similarly, the relationship between size of members and saving is compact relation among these variables in Tarai and Hill area which is statistically significant. Increment in total member increased the total saving amount of cooperative. Increasing in saving helps to generate the funds of cooperative. Likewise, the relationship between size of members and net profit is strong among these variables in Tarai and Hills of the study area, which is statistically significant. Thus, increment in total membership increased the total saving and credit amount of cooperative as well. Saving and credit amount has direct effects on volume of transaction and net profit of cooperative organization. Similarly, the relationship between saving and investment is a strong relationship among these variables in Tarai and Hills of the study area is statistically significant. Therefore, saving amount has direct effects on loan disbursement of cooperative. Likewise, the relationship between saving and net profit is found to have a strong positive correlation among these variables in Tarai and medium relationship between saving and net profit in Hills of the study area which is significant. Hence, there should been increase in saving and credit (loan) activities to gain the high profit of the cooperative. Otherwise, it is impossible to gain net profit without increase in saving and give loan activities.

The relationship between assets and net profit is no correlation in Tarai and positive correlation in Hills of the study area which is statistically insignificant. Similarly, the relationship between loan investment and loan refund has a strong positive correlation between these two variables in Tarai and in Hills area which are statistically significant. Thus, without loan investment and scheduler loan refund activities, cooperative does not achieve the goal of organization. Likewise, the relationship between loan investment and loan balance is found to have a perfect positive correlation between these variables in Hills area of Mid-Western region which is also statistically significant and strong interrelated part for the progress of cooperative organization. Hence, without loan investment and in time loan refund activities, cooperative does not complete the aim of organization. Therefore, loan collection is more important than the loan investment activities for the financial sustainability of cooperative.

This research has conducted correlation between these variables such as total membership, investment (loan), saving, assets, net profit, loan investment, loan refund and loan balance of sampled cooperatives. Apart from these, the rest of areas for further study to examine correlation between other dimensions of financial sustainability of SFCs of Mid-western Region of Nepal are yet to be considered.

As per result, the SFCs give the positive impression in bringing a remarkable change in increase of social and financial awareness, mutual sociability with different communities, improvement in saving habits, increment in women involvement in society, increase in social recognition as well. Hence, SFCs help a lot to reduce rural poverty.

After becoming the cooperative member, taking loan in high interest from other persons has decreased and the dependency on dealing with cooperative has increased. The central part of 
conclusion is that, due to access of cooperative up to rural level, people have been freed from high interest rate with individual. The majority members depositing their saving in cooperative can be regarded as one of the positive aspect and financial sustainability of SFC. It is assumed as the great achievement that SFCs have played an important role for resource management and providing service to the community people.

\section{REFERENCES}

ADBL. (1993). By-laws of Small Farmers' Cooperative Limited. Kathmandu: Agricultural Development Bank Limited.

Badal, K. (2004). Sahakari- Siddanta ra Prayog. Kathmandu: Sahakari Sahayog Samuha.

CBS. (2011). Nepal Living Standard Survey-III 2010/011. Kathmandu: Central Bureau of Statistics.

Co-operative Act-2048 (1992), National Co-operative Development Board Act-2049(1993) and Co-operative Rules-2049 (1993). Kathmandu: Law Books Management Committee, Ministry of Law, justice and Parliamentary Affairs, Government of Nepal.

Creswell, John W. (2009). Research Design: Qualitative, Quantitative and Mixed Methods Approaches (Third ed.). New Delhi: SAGE Publications India Pvt Ltd.

Devkota, K. (2009). Institutional and Financial Sustainability of Small Farmers' Cooperative in the Hill of Nepal, A Ph.D. dissertation of Faculty of Humanities and Social Sciences. Kathmandu,Nepal: Tribhuvan University.

DOC. (2015). Statistics of Cooperative Enterprises. Kathmandu: Department of Cooperatives.

GON. (2012). National Cooperative Policy, 2069 B.S. The Cooperative and Poverty Alleviation Ministry, Government of Nepal, Government of Nepal.

Kothari, C.R. (2004). Research Methodology. Methods \& Techniques, Second Edition. New Delhi: New Age International Publishers.

NCF/N.(2014). Concept Paper of First National Cooperative Congress. Kathmandu: Nepali Times, February 28.

Nepal, G. and Tiwari, L. (2017). Assessment of Impact of Cooperative on Livelihood of Its Members in Mid-western Development Region of Nepal: International Journal of Humanities and Social Science (SSRG-IJHSS), Volume 4, Issue 4 July to Aurust 2017.

Neupane, S. R. (2006). Cooperative Movement: A People based Development Approach, it's Role in the Economy of Nepal, unpublished Ph.D. thesis of Economics. New Delhi, India: Jamia Millia Islamia (Central University).

Prakash, D. (2003). The Principles of Cooperation: A look at ICA Cooperative Identity Statement, Padma-Network International. New Delhi, India.

Thakuri, C. B. (2010). An Anatomy of Cooperative Movements in Nepal. Kathmandu, Nepal: Upkar Prakashan.

Tiwari, L. (2015). Role of Small Farmers Cooperative Limited (SFCL) in the Economic Development of Surkhet District, Nepal, A M.Phil. Dissertation of Faculty of Humanities and Social Sciences. Kathmandu,Nepal: Tribhuvan University. 